\title{
PENDAMPINGAN PEMBANGUNAN RUMAH SAKIT LOMBOK HOSPITAL DI KEC. PRINGGABAYA KAB. LOMBOK TIMUR
}

\author{
Siti Nurul Hijah ${ }^{1)}$ \\ ${ }^{1)}$ Fakultas Teknik Program Studi Teknik Sipil Universitas Islam Al-Azhar Mataram \\ e-mail : nurulhijah.nh@gmail.com
}

\begin{abstract}
Abstrak
Kabupaten Lombok Timur merupakan kabupaten dengan jumlah penduduk terbanyak di provinsi Nusa Tenggara Barat. Berbagai permasalahan pelayanan terhadap masyarakat tidak mampu sering kali terabaikan dalam proses pelayanan awal hingga akhir. Hal inilah yang mendasari perlunya penambahan sarana pelayanan kesehatan di Kabupaten Lombok Timur yang perlu mendapat perhatian. Di sisi lain kemampuan keuangan pemerintah Kabupaten Lombok Timur saat ini belum mampu mengalokasikan dana pembangunan dan perbaikan sarana pelayanan kesehatan sesuai kebutuhan. Berdasarkan hal tersebut perlu dilakukan pendampingan secara teknis untuk membantu terwujudnya konstruksi pembangunan rumah sakit yang aman, terjangkau dan merata bagi masyarakat tidak mampu dan memperlancar proses pembangunannya sampai selesai.

Tujuan dari program pendampingan ini adalah untuk membantu menyediakan sarana dan prasarana pelayanan kesehatan dalam menjamin terlayaninya kebutuhan masyarakat akan pelayanan kesehatan yang berkualitas dan memadai serta biaya yang terjangkau. Metode yang digunakan dalam kegiatan ini adalah mensosialisasikan, memberikan arahan dan bimbingan kepada masyarakat tentang rencana pembangunan rumah sakit dan melakukan pendampingan dan advokasi teknis mulai dari peninjauan lapangan, design sampai proses pelaksanaan pembangunan rumah sakit. Hasil yang dicapai dalam kegiatan ini terwujudnya pelaksanaan pembangunan rumah sakit yang optimal baik kualitas dan kuantitas dan dapat dipertanggung jawabkan secara teknis sehingga berdampak dalam peningkatan pelayanan kesehatan terutama bagi masyarakat tidak mampu.
\end{abstract}

Kata Kunci : Pembangunan, Rumah Sakit, Lombok Hospital

\section{PENDAHULUAN}

Kabupaten Lombok Timur adalah salah satu Kabupaten diantara sepuluh Kabupaten / Kota yang ada di provinsi Nusa Tenggara Barat. Secara administrasi Kabupaten Lombok Timur terdiri dari 20 Kecamatan, 254 Desa/Kelurahan, 1266 Dusun/Lingkungan dengan luas wilayah 1.230,76 Km² serta penduduk kabupaten Lombok Timur 1.289.907 jiwa, merupakan kabupaten dengan jumlah penduduk terbanyak di provinsi NTB. Sebagai tantangan ke depan adalah bagaimana meningkatkan mutu dan kualitas manajemen kesehatan melalui penguatan perencanaan dan penganggaran sehingga tepat sasaran, tepat pelaksanaan serta tepat pemanfaatan.

Keberadaan sarana Kesehatan pada Dinas Kesehatan saat ini yang tercatat sebagai asset pemerintah Kabupaten Lombok Timur yaitu bangunan Puskesmas sebanyak 29 Puskesmas, 87 Puskesmas Pembantu dan 194 Poskesdes, RSUD sebanyak 1 dan RS Swasta sebanyak 2 buah.

Kesehatan adalah Bagian prinsip pokok kehidupan hak asasi manusia yang harus dinikmati oleh semua orang secara merata. Pemerintah memandang pentingnya kesehatan sebagai investasi dimasa yang akan datang karena kesehatan merupakan pondasi yang kuat untuk mendukung pembangunan sektor lainnya. 
Pembangunan dibidang kesehatan menjadi salah satu prioritas pembangunan pemerintah kabupaten Lombok Timur, karena merupakan salah satu upaya mencapai visi "Mewujudkan Lombok Timur yang adil, sejahtera dan aman". Selain itu juga merupakan upaya nyata dalam mencapai visi pembangunan kesehatan kabupaten Lombok Timur yaitu "mewujudkan masyarakat Lombok Timur yang sehat, produktif, dan berkualitas". Untuk mewujudkan visi tersebut diperlukan realisasi dan percepatan melalui penyelenggaraan pembangunan sarana Kesehatan yang di sertai berbagai terobosan penting yang dapat menjangkau seluruh lapisan masyarakat Lombok Timur, tidak terkecuali untuk masyarakat miskin atau tidak mampu.

Berbagai permasalahan pelayanan terhadap masyarakat miskin atau tidak mampu sering kali terabaikan, dan menjadi kelompok yang sering terdiskriminasi dalam proses pelayanan awal hingga akhir. Hal inilah yang mendasari perlunya sarana pelayanan rujukan spesifik berdasar tingkat perekonomian dan merupakan tantangan tersendiri bagi Kabupaten Lombok Timur tanpa menghilangkan fungsi pokok sebuah Rumah Sakit. Disamping itu, pemberdayaan tenaga Kesehatan di Wilayah Kabupaten Lombok Timur saat ini harus mendapat perhatian, hal ini di sebabkan sudah mulai tidak seimbangnya produksi tenaga kesehatan yang di hasilkan oleh institusi pendidikan dibandingkan dengan institusi serapannya dalam hal ini sarana pelayanan Kesehatan seperti Rumah Sakit.

Seiring perkembangan otonomi daerah, dengan bertambahnya jumlah Desa dalam wilayah administrasi Kabupaten Lombok Timur berdampak perlunya di lakukan penambahan sarana dan prasarana pelayanan Kesehatan dasar yang dapat memberikan pelayanan kepada masyarakat secara lebih merata dan terjangkau. Di sisi lain kemampuan keuangan pemerintah Kabupaten Lombok Timur saat ini belum mampu mengalokasikan dana pembanguanan dan perbaikan sarana pelayanan kesehatan sesuai kebutuhan.

Berdasarkan hal tersebut diatas penulis melalui pengabdian masyarakat melakukan pendampingan untuk membantu terwujudnya pembangunan rumah sakit bekerjasama dengan Yayasan Lombok Sahabat Bangsa dan VLOK Foundation Holland, untuk bisa membantu pembangunan Rumah sakit tersebut.

\section{Maksud}

Maksud pendampingan pembangunan Rumah Sakit Lombok Hospital adalah memberikan pendampingan dan advokasi teknis dari proses perencanaan/desain sampai dengan pelaksanaan pembangunan, sehingga pelaksanaan pekerjaan fisik memperoleh hasil yang optimal baik kualitas dan kuantitas dan dapat dipertanggung jawabkan secara teknis serta waktu pelaksanaan tepat sesuai yang direncanakan

\section{Tujuan}

Membantu menyediakan sarana dan prasarana pelayanan kesehatan rujukan yang merata dan terjangkau dalam rangka meningkatkan pelayanan kesehatan di Kabupaten Lombok Timur sesuai standar kesehatan.

Menjamin terlayaninya kebutuhan masyarakat akan pelayanan kesehatan yang berkualitas dan memadai serta biaya yang terjangkau.

\section{METODE PELAKSANAAN}

Pendampingan pembangunan Rumah Sakit Lombok Hospital di Kabupaten Lombok Timur, untuk memperlancar pembangunan dan penyediaan sarana dan prasarana pelayanan kesehatan dilakukan secara bertahap sebagai berikut :

Tahap pertama peninjauan lapangan : melakukan survey lokasi pembangunan Rumah Sakit yang telah ditetapkan oleh pemerintah daerah kabupaten Lombok timur dengan tujuan untuk memperoleh 
data dan informasi yang diperlukan guna menyiapkan pelaksanaan pekerjaan. Lokasi pekerjaan berada di Desa Apitaik Kecamatan Pringgabaya Kabupaten Lombok Timur.

Tahap kedua memfasilitasi masyarakat dalam melakukan musyawarah untuk memutuskan pelaksanaan kegiatan. Musyawarah ini terbuka bagi segenap anggota masyarakat untuk menghadiri dan memutuskan prioritas masyarakat yang akan menerima manfaat dari pembangunan sarana fisik kesehatan ini.

Tahap ketiga memberikan arahan, bimbingan dan petunjuk kepada masyarakat tentang pelaksanaan pekerjaan serta solusi terhadap masalah-masalah yang timbul dilapangan sepanjang tidak bertentangan dengan kaidah-kaidah teknis dan sesuai dengan aturan yang berlaku. Masyarakat adalah pelaku utama dalam pelaksanaan kegiatan ini. Para pekerja yang terlibat dalam pembangunan sarana/prasarana program ini berasal dari warga penerima manfaat.

Tahap keempat perencanaan kegiatan : untuk memenuhi dan menyediakan sarana fisik kesehatan yang memenuhi kualitas, kuantitas maupun kontinuitas kepada masyarakat kurang mampu perlu mempersiapkan perencanaan pembangunan Rumah Sakit Lombok Hospital dengan rincian kegiatan sebagai berikut : Penggambaran Design Gambar, Pembuatan Rencana Kerja dan Syarat-Syarat kerja dan penghitungan Rencana Anggaran Biaya pelaksanaan kegiatan

\section{Konstruksi Fisik Rumah Sakit Lombok Hospital}

Dalam tahap pelaksanaan pembangunan konstruksi pendampingan teknis kepada masyarakat tentu sangat diperlukan. Pendampingan dan pengendalian melalui pemantauan (monitoring) menjadi hal yang penting di dalam proses pembangunan konstruksi. Monitoring dan pendampingan harus dilakukan baik secara berkala maupun terus menerus dengan tujuan mengukur apakah pembangunan konstruksi masih sesuai dengan rencana kerja dan spesifikasi yang telah ditetapkan. Obyek monitoring berupa masukan dan keluaran dari proses pelaksanaan konstruksi, dengan membandingkan hasil pekerjaan yang dapat dicapai terhadap yang direncanakan sesuai dengan yang ditetapkan dalam spesifikasi.

1. Pertama Penyediaan tenaga kerja dimana sebagian besar para pekerja yang melaksanakan pembangunan adalah masyarakat sekitar lokasi pembangunan. Hal ini perlu dilakukan guna menggugah rasa memiliki terhadap bangunan rumah sakit disamping meningkatkan nilai ekonomi keluarga. Keterlibatan masyarakat sekitar bukan hanya terbatas sebagai tenaga kerja, akan tetapi pengadaan material lokal seperti batu kali, batu bata, pasir, kerikil dan tanah urug juga dapat dipenuhi oleh masyarakat sekitar lokasi.

2. Kedua pembuatan rencana jadwal pelaksanaan (Time Schedule) dalam bentuk kurva "s" yang dilengkapi dengan grafik prestasi yang direncanakan berdasarkan butir-butir komponen pekerjaan di lapangan dengan berpedoman pada rencana pelaksanaan mingguan yang harus dibuat pada saat memulai pelaksanaan.

3. Ketiga penyediaan perlengkapan dan penjagaan keamanan berfungsi untuk menyediakan/mendirikan barak kerja dan gudang penyimpanan alat dan bahan bangunan untuk keperluan pekerjaan konstruksi, menyediakan air minum yang cukup di tempat pekerjaan untuk para pekerja, kotak obat yang memadai, serta perlengkapan-perlengkapan keselamatan kerja, bila terjadi kecelakaan di tempat pekerjaan,

4. Keempat penyediaan bahan bangunan yang memenuhi persyaratan mutu dan jumlah/volumenya sesuai dengan tahap-tahap pelaksanaan kosntruksi sesuai dengan jadwal pelaksanaan..

Mutu bahan yaitu : Semua bahan dan pengerjaan harus sesuai dengan spesifikasi teknis.

Batu dan Tanah Urug adalah batu harus dari batu yang keras, tidak porus berukuran berat sesuai yang di syaratkan dalam gambar rencana dan minimal ketiga sisinya merupakan hasil pecahan. Berat jenis batu yang dipersyaratkan adalah $2500 \mathrm{~kg} / \mathrm{m}^{2}$, sedangkan tanah urug yang disyaratkan 
harus tanah yang mengandung batuan $60 \%$ dari material urugan itu sendiri;

Air kerja adalah air yang digunakan sebagai media untuk adukan pasangan plesteran, beton, dan penyiraman guna pemeliharaannya, harus air tawar yang bersih, tidak mengandung minyak, garam, asam dan zat organik lainnya yang telah dinyatakan memenuhi syarat sebagai air untuk keperluan pelaksanaan konstruksi oleh laboratorium. Bila air yang dipergunakan dari sumber PDAM, maka tidak lagi diperlukan rekomendasi laboratorium;

Semen Portland (PC) yang digunakan adalah PC jenis I harus satu merk untuk penggunaan dalam pelaksanaan satu satuan komponen bangunan, belum mengeras sebagian atau seluruhnya. Penyimpanannya harus dilakukan dengan cara dan di dalam tempat (gudang) yang memenuhi syarat untuk menjamin keutuhan kondisi sesuai persyaratannya;

Pasir (Psr) yang digunakan adalah pasir sungai, berbutir keras, bersih dari kotoran, lumpur, asam, garam dan bahan organis lainnya, yang terdiri atas Pasir untuk urugan adalah pasir dengan butiran halus, yang lazim disebut pasir urug, pasir untuk pasangan adalah pasir dengan ukuran butiran sebagian terbesar adalah terletak antara 0,075-1,25 mm yang lazim dipasaran disebut pasir pasang, pasir untuk pekerjaan beton adalah pasir cor yang gradasinya mendapat rekomendasi dari laboratorium.

Kerikil (Krk) untuk beton harus menggunakan kerikil dari batu kali pecah, bersih dan bermutu baik serta mempunyai gradasi dan kekerasan sesuai dengan syarat-syarat yang tercantum dalam PBI 1971.

Batu belah harus dari batu kali/Gunung yang keras, tidak porus berukuran berat sesuai yang di syaratkan dalam gambar rencana dan minimal ketiga sisinya merupakan hasil pecahan.

5. Kelima pembuatan shop drawing (gambar kerja) dan pembuatan as built drawing (gambar sesuai pelaksanaan) adalah gambar rancangan pelaksanaan yang tidak mengalami perubahan dalam pelaksanaannya.

Tahapan pekerjaan yang harus dikerjakan dalam Pembangunan Rumah Sakit Lombok Hospital meliputi : Pekerjaan Persiapan, Pekerjaan Tanah dan Pasir, Pekerjaan Pasangan, Pekerjaan Beton, Pekerjaan Plesteran dan Lantai, Pekerjaan Kayu, Pekerjaan Pengunci/Penggantung, Pekerjaan Atap dan Plafond, Pekerjaan Instalasi Listrik, Pekerjaan Sanitasi, Pekerjaan Pengecatan dan Pekerjaan Lain-lain. Adapun persyaratan pelaksanaan pembangunan Rumah Sakit Lombok Hospital adalah sebagai berikut :

Pekerjaan persiapan meliputi pekerjaan pengukuran dan pemasangan bouwplank dengan menggunakan bahan kayu klas III ukuran 5/7 dan 2/20, cat warna merah. Pekerjaan tanah dan pasir meliputi pekerjaan galian, urugan tanah, urugan pasir dimana seluruh pekerjaan galian dilakukan sampai pada kedalaman sesuai dengan gambar rancangan pelaksanaan, lubang galian harus dibuat yang cukup guna memperoleh ruang kerja yang cukup dan kemiringan sisi-sisinya tidak mudah longsor, tanah bekas galian diletakkan pada sisi-sisi galian sedemikian rupa sehingga tidak mengganggu jalannya pekerjaan galian dan tanah bekas galian tidak dapat longsor ke dalam galian, pekerjaan pengurugan kembali dilaksanakan setelah pekerjaan galian dan konstruksi yang memerlukannya selesai dikerjakan, urugan sirtu kembali, hendaknya dipadatkan kembali dengan menggunakan mesin pemadat (Compactor).

Pekerjaan pasangan dinding bata yang dipakai pada bangunan ini, menggunakan bata yang berkualitas baik, utuh dan tidak cacat serta bata yang dipakai harus dengan ukuran yang sama, bata merah sebelum dipasang harus direndam dahulu dalam bak atau drum air, sampai jenuh yang harus disiapkan dilapangan, pasangan dinding bata merah dipasang sesuai dengan Gambar Kerja yang sudah ada dan untuk pasangan tembok bata menggunakan pasangan setengah bata, perekat yang dipergunakan untuk pasangan bata adalah sebagai berikut : untuk pasangan tembok bata biasa menggunakan campuraan $1 \mathrm{Pc}: 5$ Ps dan untuk pasangan tembok trasram menggunakan campuran $1 \mathrm{Pc}: 3$ Ps dipasang pada tempat-tempat yang ditentukan yaitu dari atas sloof $( \pm 60 \mathrm{~cm}$ dari atas 
lantai) dan $+200 \mathrm{~cm}$ pada dinding km/wc sesuai dengan Gambar Kerja dan Detail, hubungan kolom beton dengan pasangan bata maupun kusen diberi angker dari besi $\varnothing 10 \mathrm{~mm}$ dengan jarak maksimal $80 \mathrm{~cm}$, bata yang mentah, retak/tidak memenuhi syarat dan tetap terpasang agar dibongkar dan segera diganti dengan bata yang memenuhi syarat tersebut.

Pekerjaan beton adalah pekerjaan beton, pekerjaan beton bertulang dan begisting tetap mengacu kepada tata cara perhitungan struktur beton untuk bangunan gedung (SNI-03-2847-2002). Beton yang terdiri dari beberapa unsur material harus merupakan bagian yang menyatu dan kokoh dengan komposisi campuran yang telah ditetapkan untuk mendapatkan kekuatan yang diinginkan. Dalam pelaksanaan pekerjaan ini dilaksanakan pekerjaan beton bertulang meliputi kolom, balok gantung, lisplank, sloof, plat, kolom praktis dan ring balok sesuai ukuran dalam gambar. Pekerjaan beton tidak bertulang meliputi beton rabat. Bahan yang dipakai : Air, Semen (Portland Cement), Agregat Halus (Pasir), Agregat Kasar (Kerikil) dan Besi Beton.

Pekerjaan plesteran dan lantai terdiri dari pekerjaan plesteran beton, plesteran dinding batu bata, pekerjaan benangan dan pekerjaan pemasangan lantai. Pada pekerjaan plesteran seluruh permukaan beton/pasangan dinding bata yang tampak harus menghasilkan permukaan yang halus dan rata. Bila pelaksanaan pekerjaan beton/pasangan dinding bata tidak dapat menghasilkan permukaan yang halus dan rata, maka permukaan tersebut harus diplester hingga menghasilkan permukaan seperti yang dimaksudkan di dalam Gambar Rancangan Pelaksanaan. Mortar untuk plesteran adalah campuran 1 PC : 3 PS yang diaduk secara benar-benar homogen. Ketebalan plesteran rata-rata adalah $1,5 \mathrm{~cm}$. Plesteran harus diakhiri dengan acian halus dari adukan air semen (PC). Pekerjaan benangan harus menghasilkan akhiran yang benar-benar siku dan lurus. Untuk pemasangan lantai adalah pekerjaan pemasangan keramik lantai 40x40 cm, kualitas I/A motif, dinding ruangan menggunakan keramik lantai $40 \times 40 \mathrm{~cm}$, kualitas I/A motif, lantai KM/WC memakai keramik 25 x $25 \mathrm{~cm}$ (Motif) kualitas I/A motif un polish, keramik dinding KM/WC memakai keramik 25 x $40 \mathrm{~cm}$ (motif) kualitas I /A motif. Semua ubin tersebut dapat menggunakan produk yang telah memiliki SII dan memenuhi syarat PUBI 1972.

Pekerjaan kayu meliputi pekerjaan Rangka Daun Pintu dan segala sesuatu yang termasuk pekerjaan ini mengunakan Kayu Kelas II, untuk persyaratan bahan adalah semua kayu yang dipakai harus kering, berumur tua, lurus dan tidak retak, tidak bengkok serta mempunyai derajat kelembaban kurang dari 15\% dan memenuhi persyaratan yang tercantum dalam PKKI 1971-NI.5.

Semua kayu harus terlebih dahulu diawetkan dengan bahan anti rayap (Perendam garam wolfman). Untuk bahan Rangka Pintu kayu harus dalam keadaan baik dan memenuhi persyaratan.

Rangka daun pintu dan jendela kayu harus diserut dan menghasilkan bidang yang rata, rangka harus betul-betul kaku, lurus, kokoh dan rata agar dapat dengan mudah ditutup/dibuka.

Penyambungan panel pintu dan jendela harus menggunakan pasak dan lem kayu.

Pekerjaan kayu yang tidak rapi, kasar, bengkok dan tidak menggunakan bahan yang telah ditentukan, harus dibongkar dan diganti.

Pekerjaan Pengunci/Penggantung adalah semua kunci yang digunakan adalah sekualitas Gradino/Solid dua putaran, finish stainless tiap kunci harus mempunyai 3 anak kunci dengan panjang body minimal $20 \mathrm{~cm}$. Untuk pintu dua daun harus dipasang sloot tanam besar (expagnolet) sepanjang $25 \mathrm{~cm}$ pada bagian pinggir/tebal atas bawah, untuk pintu satu daun cukup dipasang sloot sepanjang 3" pada bagian pinggir sedangkan untuk tiap daun jendela dipasang 2 buah. Engsel yang digunakan untuk pintu yang berhubungan dengan luar jenis kupu-kupu panjang 4" merk setara Gradino/Solid dan dipasang 3 buah untuk tiap daun pintu. Sedangkan daun jendela dipakai engsel ukuran 3 setara Belleza ", tiap daun jendela dipasang 2 buah engsel. Hak angin panjang $30 \mathrm{~cm}$ dipasang $2 \mathrm{bh}$ untuk setiap daun jendela. Hardwere kunci gantung, engsel harus diminyaki agar berfungsi baik. Kunci dan alat penggantung yang terpasang ternyata tidak berfungsi, harus dibongkar/diganti.

Pekerjaan Atap dan Plafond meliputi pekerjaan gantungan plafond, penutup plafond dan list gipsum dengan bahan gantungan plafond menggunakan tulangan 40x40 sebagai tulangan induk dan 40x40 sebagai tulangan bagi, sedangkan dibagian tembok harus dipasangkan corp engel. Penutup plafond 
mengunakan gypsum $9 \mathrm{~mm}$. Sebelum pemasangan rangka plafond harus dilakukan pengukuran elevasi sehingga diperoleh tulangan plafond yang rata, col engel dipasangan pada tembok dengan mengunakan skrouw sedangkan tulangan plafond dipasang dengan pola 60x60 dan diberikan penggantung. Penutup plapond dipasang dengan rapi dengan toleransi nat maksimal $3 \mathrm{~mm}$ Pekerjaan Instalasi Listrik bahan yang dipakai dalam pekerjaan ini adalah kabel NYA, stop kontak dan saklar menggunakan merk sekualitas Vimar, Broco atau Panasonic, lampu tipe LED Spot Light 5 Watt, 9 watt dan 10 watt. Phillips/Panasonic, armature lampu SL model gantung sekualitas Broco/Vimar.

Pekerjaan Sanitasi termasuk di dalam lingkup pekerjaan air bersih dan air buangan ini adalah pekerjaan suplay air bersih dan perlengkapannya dan bahan yang digunakan dalam pekerjaan ini adalah Pipa PVC 4", 3", dan 1/2" dipasang pada tempat sesuai gambar rancangan pelaksanaan Perlengkapan-perlengkapan sambungan pipa, terdiri atas knee, sok, elbow, penutup akhir, reducing sock, faucet sock, socket. Semua perlengkapan tersebut menggunakan merk yang sama. pipa dengan diameter 1/2" atau ukuran lain sesuai gambar dipasang pada semua jaringan air bersih. Pada sambungan tersebut, kran air diameter 1/2" disambung dengan faucet sock, disambung dengan reducing sock/reducing sock dan Tee 1/2"-1/2", pada setiap belokan, digunakan knee atau elbow sesuai dengan kebutuhan demikian juga pada setiap sambungan pipa digunakan socket dan disenei, pipa yang terletak pada dinding harus masuk ke dalam batu bata minimal 2,5 cm, dan diklem (secukupnya). Pelaksanaan pekerjaan ini dilakukan sebelum pekerjaan plesteran. Kran air yang dipergunakan adalah jenis Ball Valve dengan handel siku. Sebelum plesteran dikerjakan terlebih dahulu dilakukan test kebocoran dengan memasukkan udara bertekanan 6 atmosfir ke dalam saluran air. Kemudian akan dilakukan test kebocoran dengan mengoleskan buih sabun. Pekerjaan plesteran (khususnya yang dilalui pipa) baru dapat dilakukan apabila telah tidak terdapat kebocoran, pekerjaan jaringan pipa air buangan dan perlengkapannya septicktank dan peresapan terbuat dari buis beton dengan bentuk dan dimensi seperti dalam gambar rancangan pelaksanaan, pekerjaan pemasangan closed duduk dan closed jongkok, pemasangan wastafel dan pekerjaan lainnya yang berkaitan dengan sanitair

Pekerjaan Pengecatan dilaksanakan pada seluruh permukaan dinding dalam gedung setelah plesteran dinding benar-benar telah kering, sebelum pengecatan pada dinding, kolom dan balok di selasar luar gedung serta plafond plat beton, terlebih dahulu bidang-bidang tersebut dibersihkan dari kotoran yang melekat serta dibuat rata dengan cara menggosok dengan menggunakan kertas gosok, setelah dalam keadaan bersih, bidang-bidang yang akan dicat diplamir dengan bahan plamir campuran antara 1 lem plamir: 2 semen putih: 3 mill, setelah plamir benar-benar kering pekerjaan dilanjutkan dengan menggosok plamir hingga permukaan bidang yang akan dicat benar-benar rata, pekerjaan akhir adalah pengecatan permukaan tersebut dilaksanakan hingga pekat dan rata. Untuk pengecatan plafond seluruh permukaan yang akan di cat harus dibersihkan terlebih dahulu dari segala jenis kotoran, setelah seluruh permukaan telah benar-benar bersih, dilanjutkan dengan memberi lapisan primer menggunakan alkali resisting primer produk yang sama dengan cat yang dipakai atau setara sebanyak 1 kali lapis atau sesuai petunjuk pemakaiannnya, setelah kering dilakukan pengecatan sebanyak 2-3 lapis atau sampai benar-benar pekat dan rata, pengecatan setiap lapisnya, baru boleh dilakukan setelah lapis sebelumnya telah mengering

Pekerjaan Lain-lain yakni pembersihan lokasi dari sisa-sisa bahan kerja, bekas-bekas bongkaran begisting dan lain-lain. Pemerataan tanah bekas-bekas galian, timbunan yang masih belum rapi. Pekerjaan lainnya yang perlu dikerjakan agar pada saat penyerahan seluruh pekerjaan sudah dalam kondisi sempurna dan rapi. 


\section{HASIL DAN PEMBAHASAN}

Kegiatan pendampingan pembangunan rumah sakit Lombok Hospital dilaksanakan di lokasi mitra yaitu desa Apitaik Kec. Pringgabaya Kab. Lombok Timur. Adapun sasaran yang hendak dicapai adalah memberikan pendampingan dan advokasi teknis terhadap pelaksanaan pembangunan rumah sakit Lombok Hospital agar seluruh pekerjaan sesuai dengan spesifikasi teknis, tepat waktu, tepat mutu, tepat biaya serta dapat dipertanggung jawabkan secara teknis. Pelaksanaan pembangunan rumah sakit Lombok Hospital dilaksanakan dalam 2 tahap, yaitu tahap 1 dilaksanakan mulai bulan Juli s/d Desember 2019 dan tahap 2 dilaksanakan mulai bulan Mei s/d September 2020.

Materi pelaksanaan program pengabdian kepada masyarakat adalah memberikan pemahaman dan pengenalan teknis terhadap pekerja dan masyarakat mengenai cara kerja yang benar, pemakaian bahan material sesuai dengan Standar Nasional Indonesia, penggunaan alat kerja serta penerapan K3 terutama Alat Pelindung Diri (APD) saat bekerja.

Hasil yang sudah dicapai dalam melakukan pendampingan pembangunan Rumah Sakit Lombok Hospital di Kecamatan Pringgabaya Desa Apitaik Kabupaten Lombok Timur yang sudah dilaksanakan adalah sebagai berikut:

\section{Persiapan}

Survey Lokasi : Kegiatan survey awal peninjauan lokasi tempat pembangunan Rumah Sakit Lombok Hospital sebagai sarana fisik kesehatan yang akan digunakan oleh masyarakat Kabupaten Lombok Timur khususnya Lombok Timur bagian utara.

Perencanaan Kegiatan : Untuk memenuhi dan meningkatkan pelayanan kesehatan rujukan/rumah sakit, maka perlu mempersiapkan perencanaan pembangunan dengan rincian kegiatan adalah pembuatan Rencana Kerja dan Syarat-Syarat kerja dan penggambaran Detail Design Gambar pembangunan Rumah Sakit Lombok Hospital.

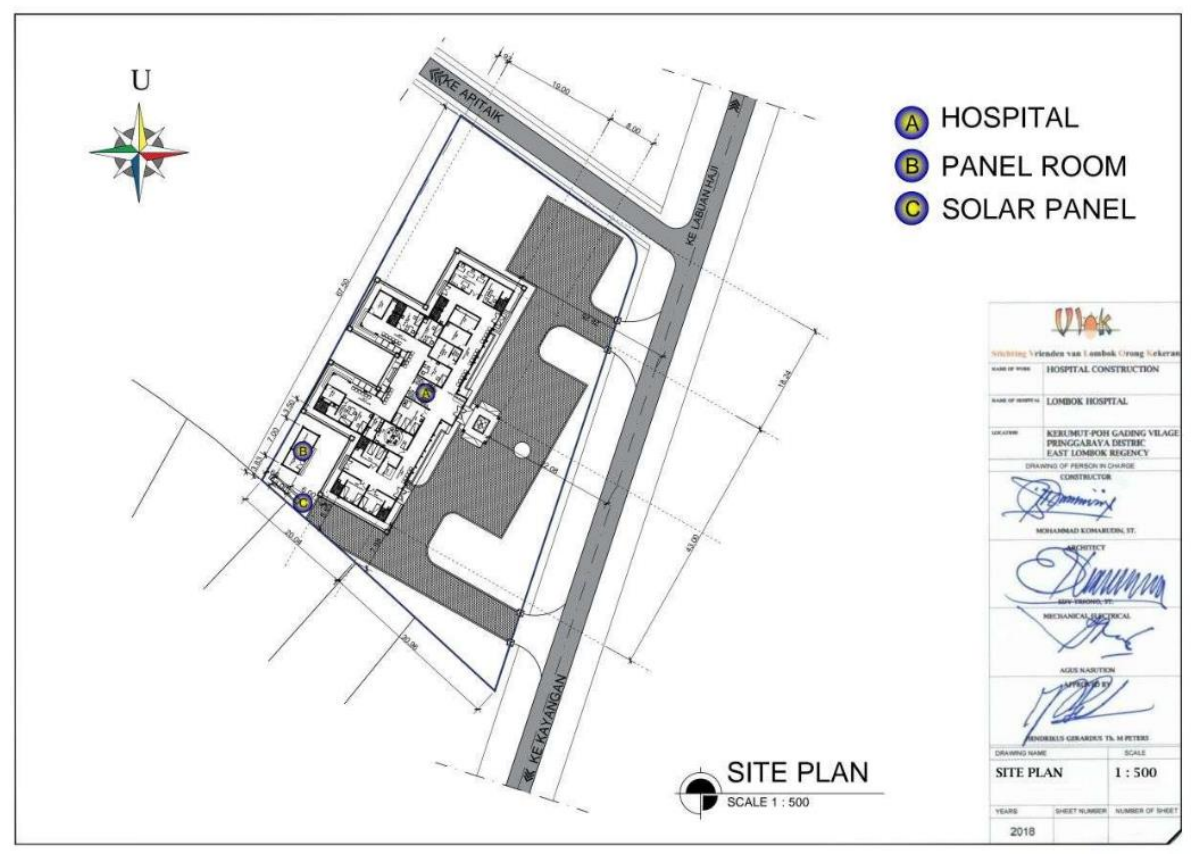

Gambar 1. Site Plan Rumah Sakit Lombok Hospital 


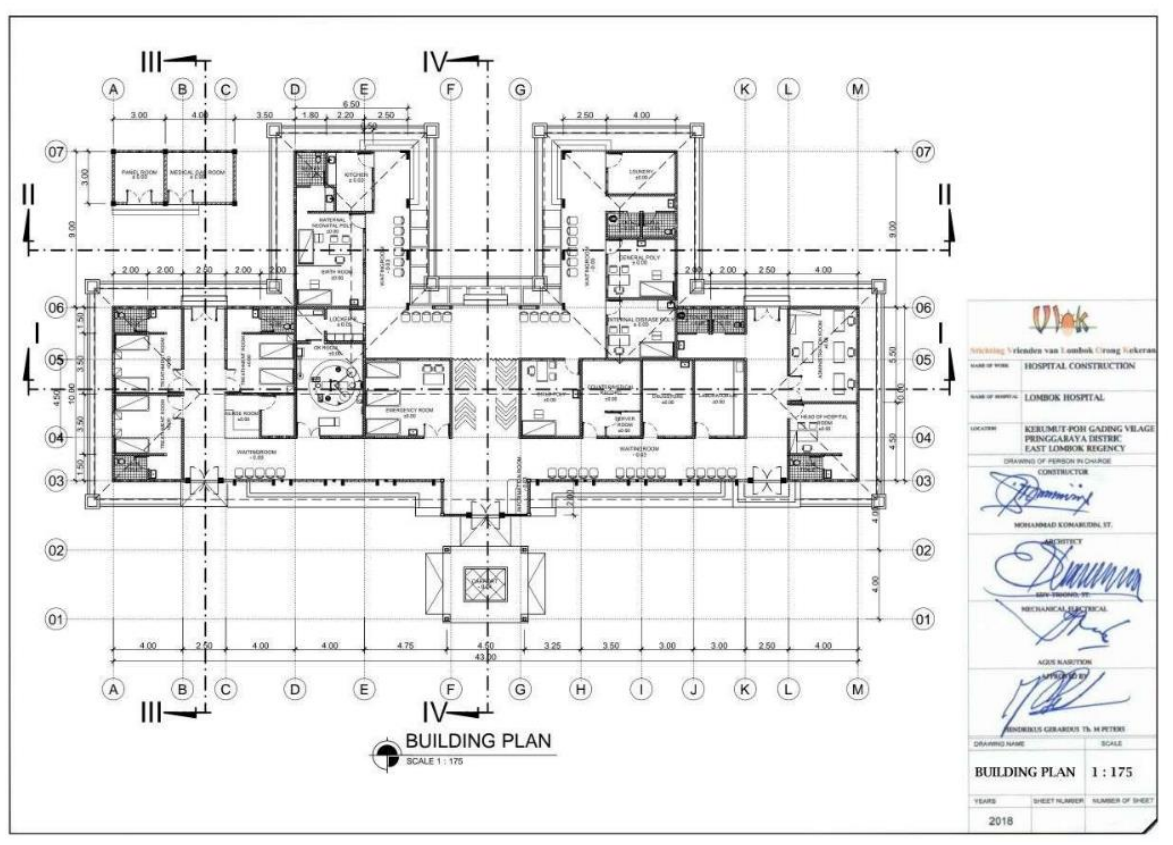

Gambar 2. Rencana Bangunan Rumah Sakit Lombok Hospital

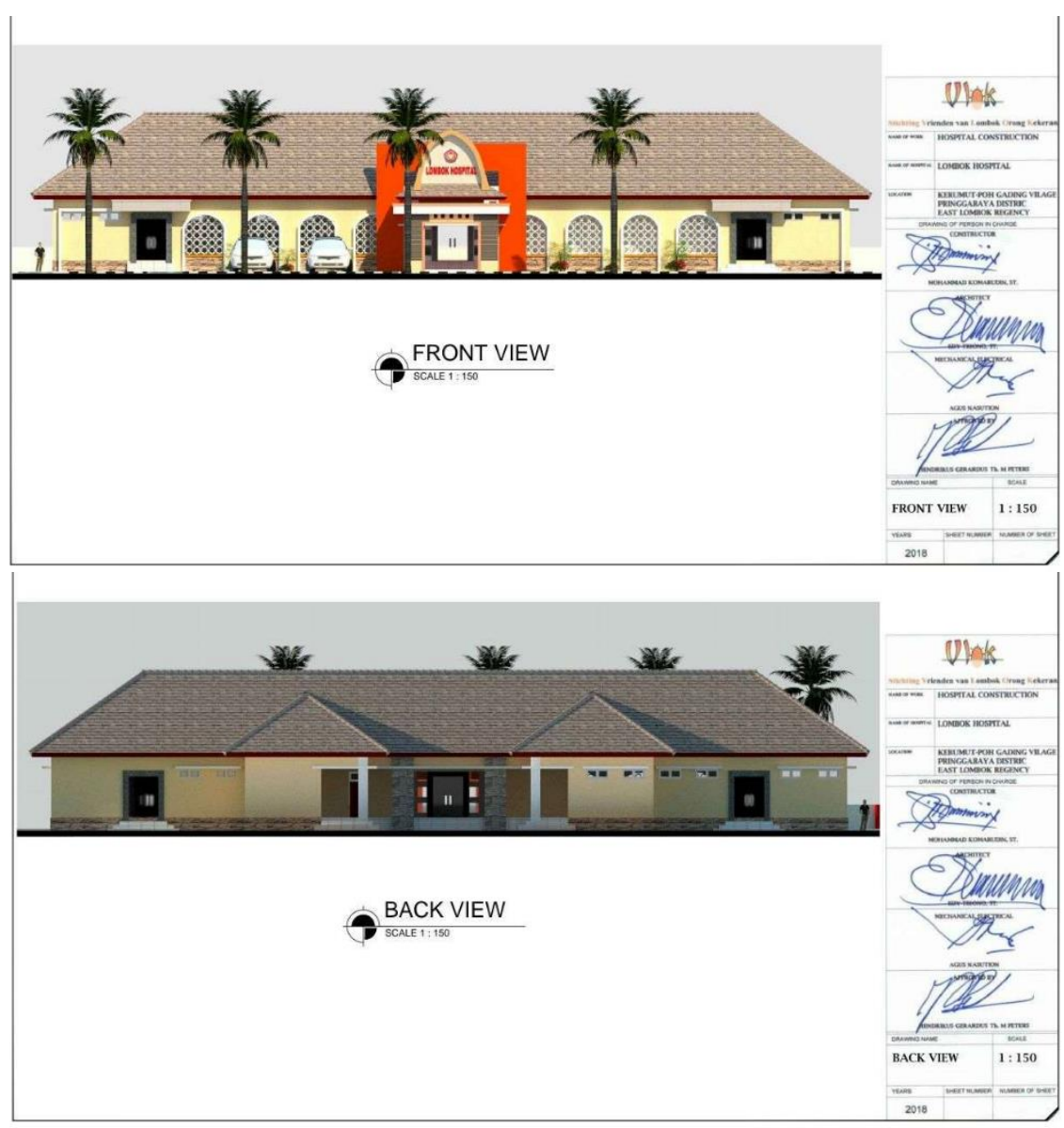

Gambar 3. Tampak Depan dan Tampak Belakang Rumah Sakit Lombok Hospital 


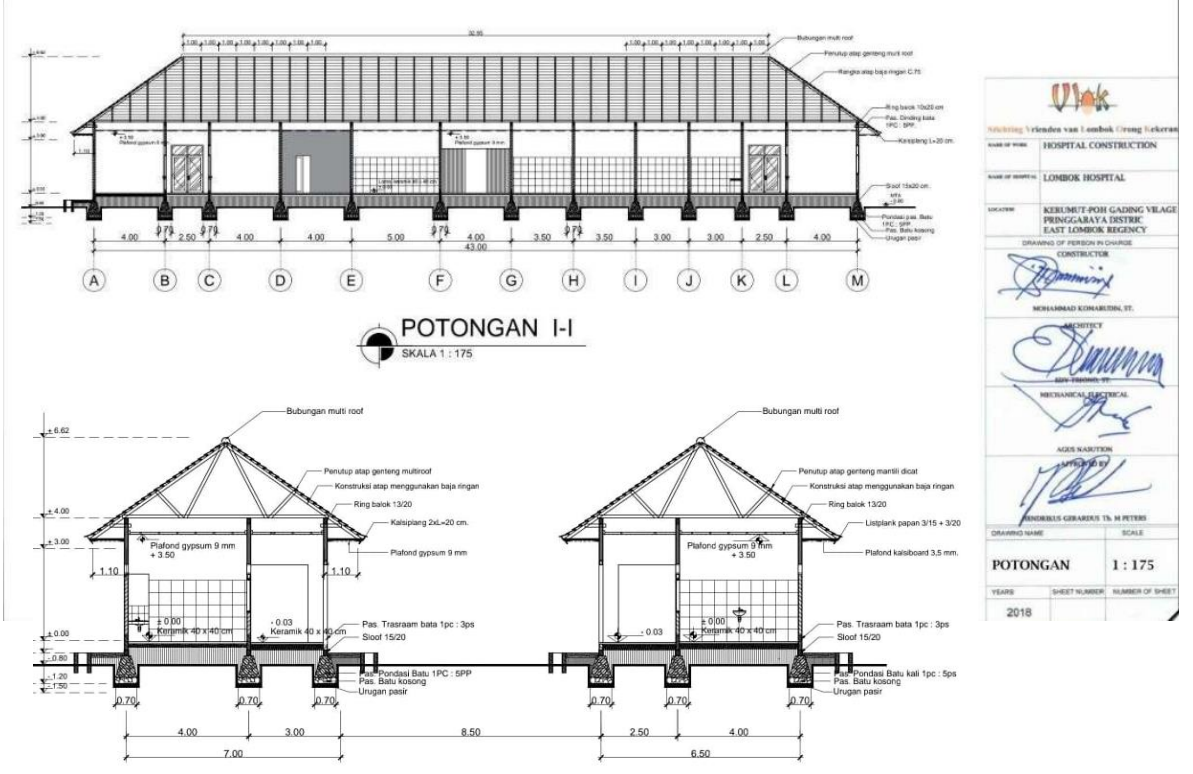

$\frac{\text { POTONGAN II-II }}{\text { SKALA : } 100}$

Gambar 4. Potongan I - I dan Potongan II - II Rumah Sakit Lombok Hospital
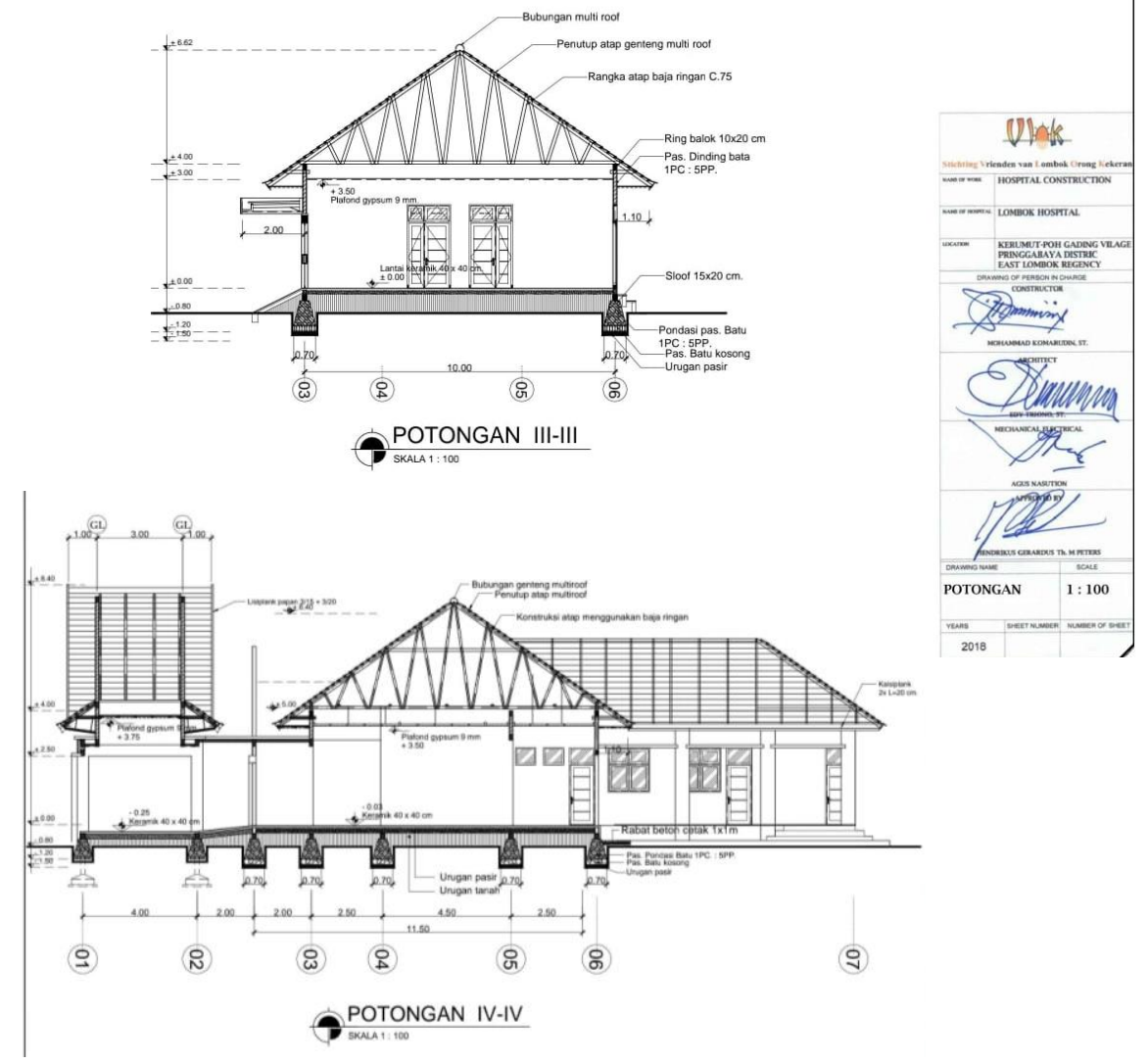

Gambar 5. Potongan III - III dan Potongan IV - IV Rumah Sakit Lombok Hospital 


\section{Pelaksanaan}

Pelaksanaan pembangunan Rumah Sakit Lombok Hospital dilaksanakan dalam dua tahap yakni tahap pertama dilaksanakan pada tahun 2019 dan tahap kedua dilaksanakan pada tahun 2020, yang dilakukan secara bersama-sama atas partisipasi masyarakat, Bupati Lombok Timur, Vlok Foundation Holland dan Yayasan Lombok Sahabat Bangsa dengan tahapan tanggung jawab masing-masing sebagai berikut :

Pertama Bupati bersedia menerima pembangunan Rumah Sakit "Lombok Hospital" yang dibantu oleh Vlok Foundation Holland, bersedia menjaga keberlangsungan pembangunan rumah sakit Lombok Hospital sampai selesai pembangunannya, Pemerintah desa Apitaik kecamatan pringgabaya bersedia menyiapkan tanah lokasi pembangunan Rumah Sakit Lombok Hospital.

Kedua Vlok Foundation Holland berpartisipasi membiayai 100\% (seratus persen) pembangunan gedung Rumah Sakit Lombok Hospital tersebut.

Tahapan pelaksanaan pembangunan Rumah Sakit Lombok Hospital sebagai berikut :

Pembersihan Lahan

Membersihkan lahan tempat pembangunan Rumah Sakit Lombok Hospital tersebut, dan melakukan pengukuran titik koordinat untuk memasang bouwplank/profil pada pembangunan rumah sakit Lombok Hospital tersebut.

Pengadaan Material dan Peralatan

Pembangunan Fisik Rumah Sakit Lombok Hospital Diawali dengan peletakan batu pertama oleh perwakilan Vlok Foundation Holland bersama Wakil Bupati Lombok Timur, Assisten II Provinsi Nusa Tenggara Barat, yayasan Lombok Sahabat Bangsa dan masyarakat Lombok Timur. Luas lahan $6.920,70 \mathrm{~m}^{2}$, luas bangunan Rumah Sakit Lombok Hospital $654,20 \mathrm{~m}^{2}$ yang terdiri dari 5 (lima) Ruang tunggu/corridor, 21 (dua puluh satu) ruang pelayanan dan Mekanikal Elektrikal.
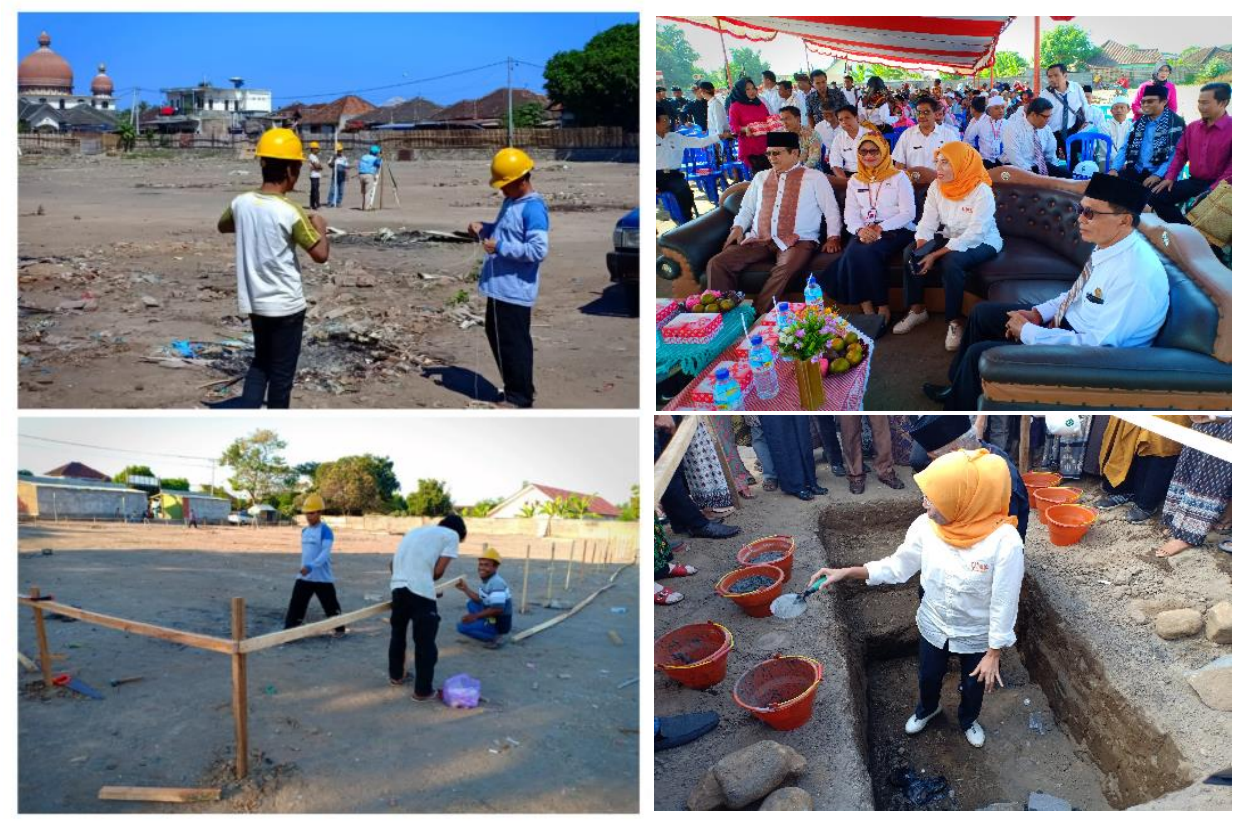

Gambar 6. Pemasangan bouwplank dan peletakan batu pertama Rumah Sakit Lombok Hospital 

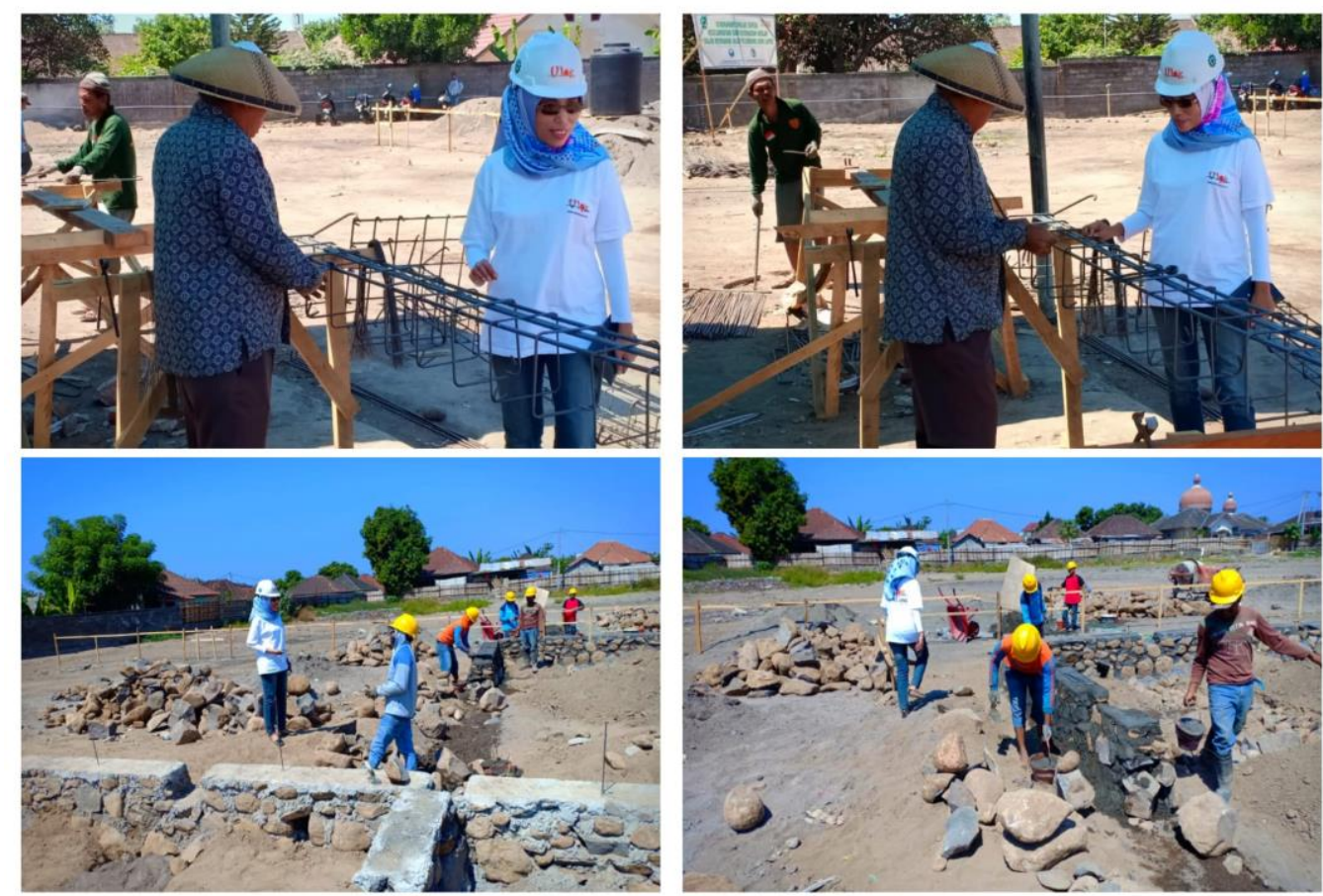

Gambar 7. Pekerjaan pembesian dan pondasi batu kali

Pembangunan fisik Rumah Sakit Lombok Hospital dilaksanakan mulai dari Pekerjaan Persiapan, Pekerjaan Tanah dan Pasir, Pekerjaan Pasangan, Pekerjaan Beton, Pekerjaan Plesteran dan Lantai, Pekerjaan Kayu, Pekerjaan Pengunci/Penggantung, Pekerjaan Atap dan Plafond, Pekerjaan Instalasi Listrik, Pekerjaan Sanitasi, Pekerjaan Pengecatan dan Pekerjaan lain-lain sesuai dengan metode yang telah ditetapkan pada Rencana Kerja dan Syarat-Syarat kerja serta sesuai Detail Design Gambar pembangunan Rumah Sakit Lombok Hospital yang telah disetujui bersama.
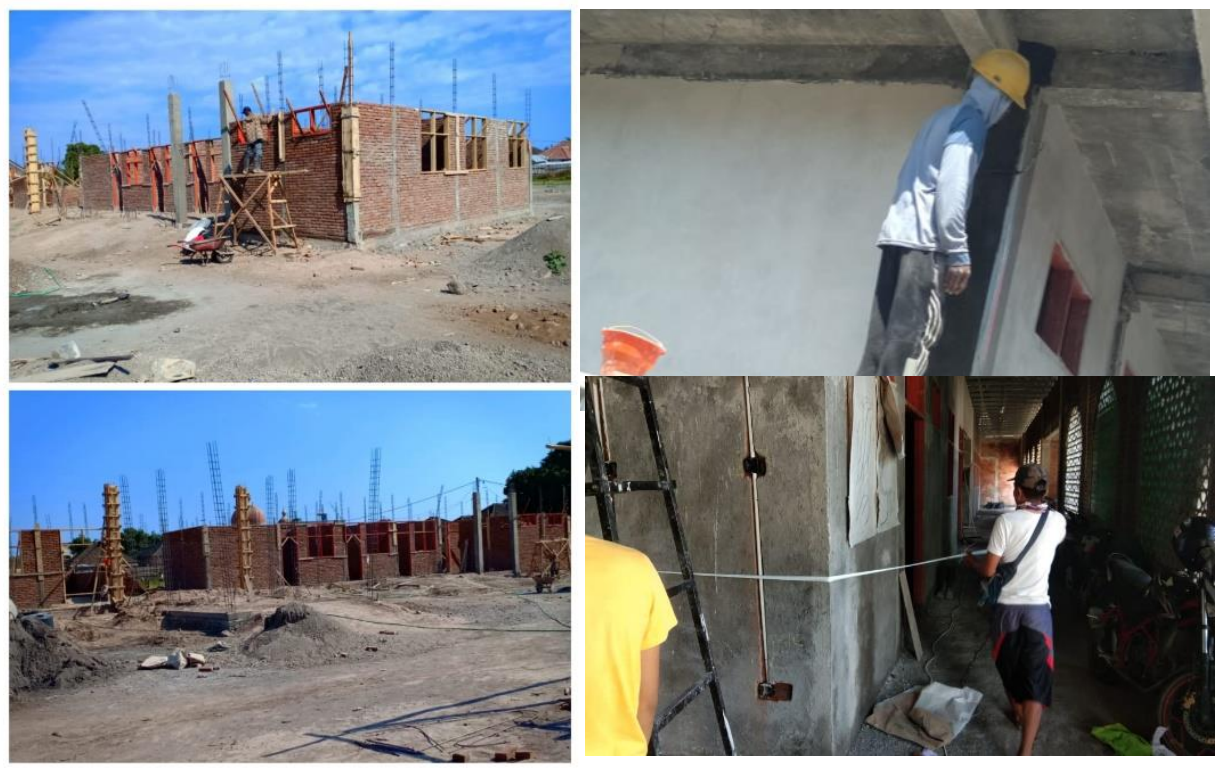

Gambar 8. Pekerjaan pasangan batu bata dan Plesteran 

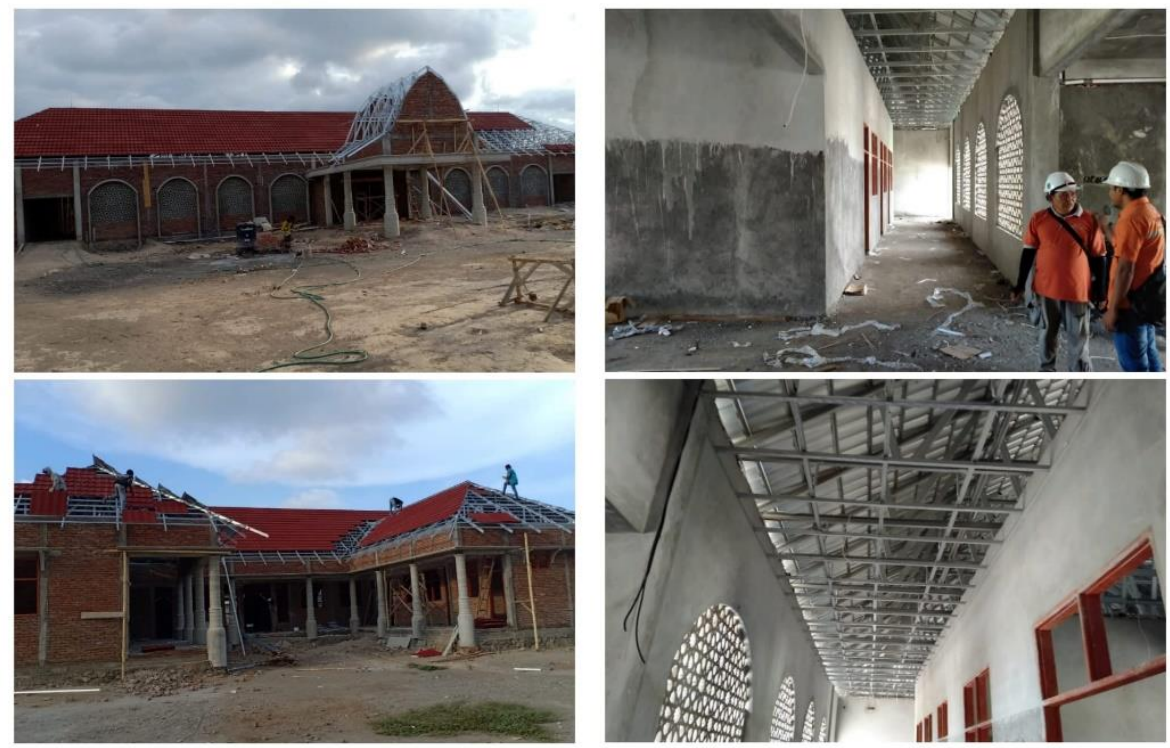

Gambar 9. Pekerjaan Atap dan Plafond
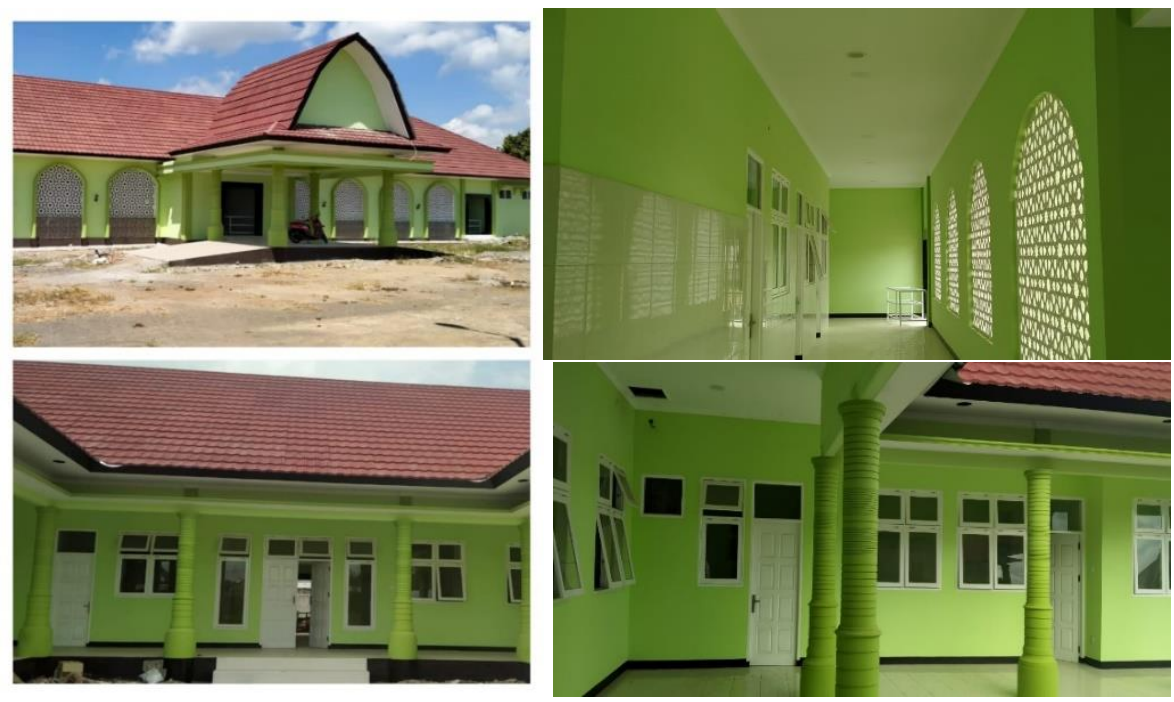

Gambar 10. Pekerjaan Finishing 100\%

\section{Potensi Keberlanjutan}

Pembangunan rumah sakit Lombok Hospital yang dilaksanakan dengan dana hibah dari Belanda masih banyak menyisakan pekerjaan rumah untuk berkembangnya sebuah rumah sakit. Rumah sakit Lombok Hospital yang dibangun saat ini baru menyiapkan sebuah bangunan rumah sakit dengan standar pelayanan minimal rumah sakit type D. Hal ini masih perlu dikembangkan dengan investasi bidang kesehatan yang masih cukup besar baik sarana dan prasarana maupun sumber daya manusia. Disamping hal tersebut tentu manajemen harus bekerja ektra keras untuk meyakinkan berbagai pihak terutama pemerintah daerah untuk dapat memberikan dukungan penuh guna keberlanjutan operasional rumah sakit. Tentu hal ini akan dilakukan dengan sepenuhnya oleh manajemen, mengingat pada saat dimulainya pembangunan, dukungan dari pemerintah kabupaten maupun provinsi begitu besar dengan antusias yang luar biasa, dan ini adalah peluang yang sangat baik, disamping manajemen harus mampu menangkap peluang yang ada saat ini seperti BPJS, CSR dari berbagai perusahaan serta mempu bekerjasama dengan berbagai Lembaga Donor baik dalam negeri maupun luar negeri.Terkait dengan hal tersebut diatas pendampingan secara teknis akan terus menerus dilakukan dalam upaya pengembangan infrastruktur rumah sakit, pemeliharaan sarana dan prasarana serta memberikan nasehat teknis kepada pihak manajemen rumah sakit. 


\section{SIMPULAN DAN REKOMENDASI}

\section{Simpulan}

Pendampingan dan pemberdayaan pada masyarakat dalam membantu terwujudnya pembangunan rumah sakit Lombok hospital di kecamatan Pringgabaya dalam melakukan penyediaan sarana fisik kesehatan untuk mendukung peningkatan akses pelayanan kesehatan yang merata dan terjangkau dalam rangka meningkatkan pelayanan kesehatan rujukan atau Rumah Sakit tipe D yang islami dan prima bagi masyarakat, terutama masyarakat miskin dan tidak mampu, dapat dilaksanakan dengan baik dan kegiatan pembangunan mencapai $100 \%$, bekerjasama dengan tim pelaksana pengabdian masyarakat bersama VLOK Foundation Holland, Yayasan Lombok Sahabat Bangsa dan Pemerintah Daerah Kabupaten Lombok Timur serta Dewan Masyarakat Sehat Kab. Lombok Timur, dimana untuk pembangunan Rumah Sakit pemerintah daerah menyiapkan tanah seluas $6.920,70 \mathrm{~m}^{2}$, VLOK Foundation Holland mendanai pembangunan Gedung Rumah Sakit Lombok Hospital sehingga semua telah berjalan sesuai yang diharapkan. Pembangunan Rumah Sakit Lombok Hospital diharapkan dapat meningkatkan derajat kesehatan masyarakat, meningkatkan pelayanan kesehatan yang optimal dan masyarakat dapat melakukan pemeliharaan dan perawatan terhadap sarana fisik kesehatan tersebut dengan baik.

\section{Rekomndasi}

Perlu dilakukan kerjasama dengan berbagai pihak baik pemerintah maupun lembaga donor untuk mewujudkan sebuah rumah sakit dengan pelayanan paripurna dan terakreditasi.

Perlu adanya bimbingan teknis kepada masyarakat setempat tentang pemeliharaan bangunan rumah sakit agar gedung tersebut konstruksinya tetap aman secara teknis.

\section{UCAPAN TERIMA KASIH}

Melalui kesempatan ini, penulis menyampaikan terima kasih dan penghargaan yang setinggitingginya kepada Vlok Foundation Holland atas bantuan biaya pada penyediaan pembangunan sarana fisik kesehatan Rumah Sakit Lombok Hospital di Desa Apitaik Kec. Pringgabaya, juga ucapan terima kasih dan penghargaan yang setinggi-tingginya kepada Bupati Lombok Timur dan seluruh masyarakat Kabupaten Lombok Timur, serta Yayasan Lombok Sahabat Bangsa dan Dewan Masyarakat Sehat Kab. Lombok Timur yang telah berperan aktif dalam mensukseskan kegiatan ini. Ucapan terima kasih juga kami sampaikan kepada Lembaga Pengabdian dan Penelitian Pada Masyarakat (LPPM) Universitas Islam Al-Azhar Mataram atas bantuan dan dukungannya sehingga pengabdian masyarakat dapat diselesaikan dengan baik.

\section{DAFTAR PUSTAKA}

Anonim, (2018), Dinas Kesehatan, Kabupaten Lombok Timur

Anonim, (2018), Detail Engineering Design (DED Lombok Hospital, Kabupaten Lombok Timur.

Anonim, (2018), Spesifikasi Teknis dan Syarat-syarat Kerja Lombok Hospital, Kabupaten Lombok Timur.

Badan Pusat Statistik Kabupaten Lombok Timur, (2019), Kabupaten Lombok Timur Dalam Angka, ISSN-0215-6057. BPS Kabupaten Lombok Timur.

Badan Standarisasi Nasional, (2002), Standar Perencanaan Ketahanan Gempa untuk Struktur Bangunan Gedung, SNI-03-1726-2002. Departemen Pekerjaan Umum, Jakarta.

NI-2, (1971), Peraturan Beton Bertulang (PBI-1971), Direktorat Penyelidikan Masalah Bangunan. Departemen Pekerjaan Umum, Bandung.

NI-3, (1970), Persyaratan Umum Bahan Bangunan di Indonesia (PUBI-1982), Direktorat Penyelidikan Masalah Bangunan. Departemen Pekerjaan Umum, Bandung. 